Wilkinson's experience the expectation of life for the patients in this regularly supervised group of patients was rather better than for people without pernicious anaemia. Of the 1,550 patients still attending his clinic, no fewer than 758 were over 70 years of age, 283 over 80 years, 39 over 90 , and one over 100 .

Patients with pernicious anaemia are never cured in the strict sense of the word, though if adequately treated their lives are in every respect as if they had been. The chief pathological change is the atrophy of the gastro-intestinal mucosa, which so far has proved irreversible. Very occasionally a patient who discontinues treatment remains well for months or even years before relapsing, but these are exceptional cases and afford no general grounds for the discontinuance of treatment. Treatment must be for life.

\section{Nasal Sprays for the Common Cold}

Q.-Manufacturers continue to advertise nasal sprays of one sort or another, some of them containing sulphonamides, antibiotics, hydrocortisone, or vasoconstrictors, for the treatment of the common cold. Is it advisable to use any or all of these medicaments in this way?

A. - The use of nasal sprays containing sulphonamides or antibiotics is to be deplored, on account of the grave danger of sensitization which it incurs. A patient who has used a nasal spray of this sort for a relatively trivial condition may find that subsequent use of the antibiotic or sulphonamide for the treatment of a serious disease is made diffcult or impossible by a sensitivity reaction. With regard to hydrocortisone, there may be a place for the use of this in the management of severe vasomotor rhinitis, seasonal or otherwise, but its use in infections of the common-cold type may, in theory, increase the risk of secondary bacterial infection. Vasoconstrictors may give temporary relief to nasal congestion and obstruction, but in the early acute stage of a cold this relief is transient and may be followed by aggravation of the symptoms. Later, when secondary bacterial infection has given rise to a purulent phase with involvement of the nasal sinuses, vasoconstrictors may be useful in permitting intermittent drainage of secretions from the affected sinuses.

\section{Injury and Central Retinal Vein Thrombosis}

Q.-Can an injury produce thrombosis of the central retinal vein or one of its branches?

A.-Central retinal vein thrombosis has been reported after a contusion as a rarity (von Wiser, 1901 ; Hillemans and Pfalz, 1905 ; Pincus, 1907 ; Cozzoli, 1916). ${ }^{1}$

\section{REFERENCE} Quoted by Duke-Elder, S., Textbook of Ophthalmology, vol. 6, p. 5854,
1954. London.

\section{Sensitivity to Arsenic and Penicillin in Tertiary Syphilitic}

Q.-A patient with tertiary syphilis is sensitive to arsenic and penicillin. How should he now be treated?

A.-Most of the antibiotics derived from lower-grade fungi are effective in the treatment of primary, secondary, and tertiary syphilis, and attempts to desensitize patients who have become intolerant of arsenic and penicillin, besides being often unsuccessful, are unnecessary.

A ten-day course of oxytetracycline or chlortetracycline ( $0.5 \mathrm{~g}$. six-hourly) is recommended. The dosage suggested by some workers, including Taggart and his collaborators, is $60 \mathrm{mg}$. per $\mathrm{kg}$. of body weight daily for six to eight days. Antibiotic therapy should be followed by a ten-week course of intramuscular injections of bismuth (injectio bismuthi, B.P., $1.5 \mathrm{ml}$. once weekly), and, as iodides assist materially in the resolution of tertiary lesions, a mixture containing potassium iodide, $15 \mathrm{gr}$. $(1 \mathrm{~g}$.), should be taken three times a day at the same time.

\section{REFERENCE}

2 Taggart, S. R., Romansky, M. J., and Landman, G. C., Amer. J. Syph., 1952, 36, 174.

\section{NOTES AND COMMENTS}

Retraction of the Prepuce.-Dr. A. E. Seligmann (Barking) writes : I was glad to read your expert's opinion ("Any Questions ?" December 8, 1956, p. 1382) that it was doubtful if the practice of gentle retraction of the prepuce from 6 months onwards would affect the incidence of necessary circumcisions. Even during the first six months it is unusual for the prepuce to be left alone, and among hundreds of male babies seen at infant welfare clinics I have not yet met one whose mother has been taught to respect the waiting period of six months. On the other hand I was surprised to learn that "most prepuces will retract spontaneously by the age of 2 or 3 years." As a school medical officer I have seen an appreciable number of schoolentrants with fully or half-adherent prepuces. In some cases mothers have even told me that the boy "had been done" as a baby, that she had been unable to persevere with it, and that the foreskin had become "stuck again" (if it was ever mobilized in the first place). I suspect that these late adherent cases do right themselves spontaneously after a few more years. Or do medical officers in the Forces still see many adherent cases ?

OUR EXPERT replies : Dr. Seligmann is clearly correct in his observations about adherent prepuces in boys at school-entrance age. In my answer to the original question I said "most prepuces" will retract spontaneously by 2 or 3 years of age. This was certainly not meant to exclude the "appreciable number" encountered by Dr. Seligmann. There are inevitably a number which take longer-and a few which will require active intervention. The answer to the question whether medical officers in the Forces will see many cases depends on the definition of "many." They certainly see "a few."

Lignocaine in Pudendal Block for Low Forceps.-Dr. Norman MorRIS (London, W.12) writes : An answer discusses the use of $0.5 \%$ lignocaine for pudendal block anaesthesia ("Any Questions?" December 29, 1956, p. 1559). Whilst advising that usually less than $80 \mathrm{ml}$. will prove adequate, nevertheless it states that "the maximum amount of this concentration that may be safely given is $200 \mathrm{ml} . "$ Dutton, ${ }^{1}$ however, in another report recommends $50 \mathrm{ml}$. of $0.5 \%$ lignocaine as "effective and safe." The majority of obstetricians would, I think, agree with this statement. Hunter ${ }^{2}{ }^{3}$ has made a careful study of the toxicity of lignocaine, and he considers that $500 \mathrm{mg}$. is the maximum safe dose, even when adrenaline is added-that is, $100 \mathrm{ml}$. of an $0.5 \%$ solution. It would be a great pity if this extremely useful anaesthetic and method fell into disrepute because of complications resultant upon unnecessary overdosage.

\section{REFERENCES}

1 Dutton, W. A. W., Lancet, 1955, 2, 1368. Hunter, A. R., Brit. J. Anaesth., 1951, 23, 153.

Books of "Any Questions?" and Refresher Course Articles.The following books are available through booksellers or from the Publishing Manager, B.M.A. House. Prices include postage. Any Questions?, Volumes 2 and 3 (8s. each); Refresher Course for General Practitioners, Volumes 2 and 3 (26s. 6d. each inland, 26s. overseas); Clinical Pathology in General Practice (22s. 3d. inland, 21s. 9d. overseas).

Correction.-In Dr. M. M. Glatt's letter on methyprylone (Journal, January 19, p. 164) the sentence beginning "Glutethimide ('doriden,' methyprylone and $\alpha$-phenyl- $\alpha$-ethyl glutarimide) ..." should read: "Methyprylone and glutethimide ( $\alpha$-phenyl- $\alpha$-ethyl glutarimide, 'doriden'), another recently introduced non-barbiturate hypnotic, are both used in many wards at the Warlingham Park Hospital as satisfactory alternatives to the barbiturates."

All communications with regard to editorial business should be addressed to THE EDITOR, BRITISH MEDICAL JOURNAL, B.M.A. HOUSE, TAVISTOCK SQUARE, LONDON, W.C.1. TELEPHONE: EUSTON 4499. TELEGRAMS : Aitiology, Westcent, London. ORIGINAL ARTICLES AND LETTERS corwarded for publication are understood to be Medical Journal alone unless the contrary be stated.

Authors desiring REPRINTS should communicate with the Publishing Manager, B.M.A. House, Tavistock Square, W.C.1. on receipt of proofs. indicate on MSS. if reprints are required, as t sent abroad.

ADVERTISEMENTS should be addressed to the Advertisement Director. B.M.A. House Tavistock Square, London, W.C.1 (hours 9 a.m. to 5 p.m.). TELEPHONE: EUSTON 4499. TELEGRAMS: Brttmedads, Westcent, London.

列 the Association. TELEPHONE: EUSTON 4499. TELEGRAMS: Medisecra. B.M.A. Scotrish OfFice: 7 Drumsheugh Gardens, Edinburgh. 